\title{
Clustering Time Series Data Mining dengan Jarak Kedekatan Manhattan City
}

\author{
Relita Buaton ${ }^{1}$, Muhammad Zarlis ${ }^{2}$, Herman Mawengkang ${ }^{2}$, Syahril Efendi $^{2}$ \\ ${ }^{1}$ Graduate Program Of Computer Science, \\ ${ }^{2}$ Department Of Computer Science \\ Faculty of Compurer Science and Information technology, \\ Universitas Sumatera Utara, Medan, Indonesia \\ bbcbuaton@gmail.com
}

\begin{abstract}
The development of information technology is very rapid and is supported by the development of storage media technology and its application to all fields that produce huge amounts of data stacks generated from various sources, therefore need new techniques in managing data stacks. Data mining has become very important as an object and research study at this time because there are many data stacks found in agencies. Data mining is an analytical process of knowledge discovery in large and complex data sets. In this study the technique used is to conduct time series data mining clusters, using proximity to manhattan city. The time series graph is carried out by the sliding window to produce an analysis of the window for each cluster result. Based on cluster results, an analysis of knowledge transformation is carried out into new knowledge obtained from data mining time series data.
\end{abstract}

Keywords: data mining cluster time series

Abstrak- Perkembangan teknologi informasi yang sangat pesat dan didukung oleh perkembangan teknologi media storage serta penerapannya pada semua bidang yang menghasilkan tumpukan data dengan kapasitas yang sangat besar yang dihasilkan dari berbagai sumber, oleh sebab itu perlu teknik baru dalam mengelola tumpukan data. Data mining menjadi sangat penting sebagai objek dan kajian penelitian saat ini karena banyaknya ditemukan tumpukan data dalam instansi. Data mining adalah proses analitis tentang penemuan pengetahuan dalam kumpulan data dengan jumlah yang besar dan kompleks. Dalam penelitian ini teknik yang digunakan adalah melakukan cluster time series data mining, dengan menggunakan jarak kedekatan manhattan city. Pada grafik time series dilakukan sliding window untuk menghasilkan analisis window untuk masing-masing hasil cluster. Berdasarkan hasil cluster, dilakukan analisa transformasi pengetahuan menjadi pengetahuan baru yang diperoleh dari data time series data mining.

Kata kunci:cluster time series data mining

\section{PENDAHULUAN}

\subsection{Data Mining}

Data mining adalah proses analitis dari penemuan pengetahuan dalam kumpulan data yang besar dan kompleks, data mining adalah disiplin ilmu yang berada dalam interseksi statistik dan ilmu komputer. Lebih tepatnya, data mining adalah hasil hibridisasi statistik, ilmu komputer, kecerdasan buatan dan pembelajaran mesin [1]. Banyak ilmuwan data ingin mengeksplorasi data, mencari informasi untuk pengetahuan yang diperoleh melalui proses pengelompokan, klasifikasi, penemuan aturan, asosiasi dan visualisasi dalam penambangan data. Dalam statistik, Time Series adalah salah satu topik yang selalu dikaitkan dengan peramalan melalui serangkaian data yang tergantung pada periode waktu. Serangkaian berkala adalah kumpulan pengamatan yang dibuat secara kronologis. Data dari seri berkala memiliki karakteristik seperti besar, dimensi tinggi dan pembaruan terus menerus. Karakteristik berikutnya adalah bahwa sifat numerik dan kontinu dari data selalu dipandang sebagai keseluruhan daripada numerik 
individual. Oleh karena itu, tidak seperti database tradisional di mana pencarian kesamaan didasarkan pada pencocokan, pencarian kesamaan dalam data seri periodik didasarkan pada pendekatan. Contoh-contoh terkenal termasuk harga saham harian di Bursa Efek Jakarta, jumlah penggunaan ponsel setiap jam di Medan, dan pembacaan permukaan laut harian di Samudera Pasifik. Banyak penelitian telah dilakukan secara berkala berdasarkan kesamaan [2].

Menurut Kusrini dan Emha Taufiq Luthfi[3], Data mining adalah suatu istilah yang digunakan untuk menguraikan penemuan pengetahuan didalam database. Data Mining adalah proses yang menggunakan teknik statistik, matematika, kecerdasan buatan, dan machine learning untuk mengektrasikan dan mengidentifikasikan informasi yang bermanfaat dan pengetahuan yang terkait dari berbagai database besar. Menurut Gartner Group Data Mining adalah suatu proses menemukan hubungan yang berarti, pola dan kecenderungan dengan memeriksa dalam sekumpulan besar data yang tersimpan dalam penyimpanan dengan menggunakan tehnik pengenalan pola seperti tehnik statistik dan matematika. Data mining terdiri dari beberapa tahapan yaitu:

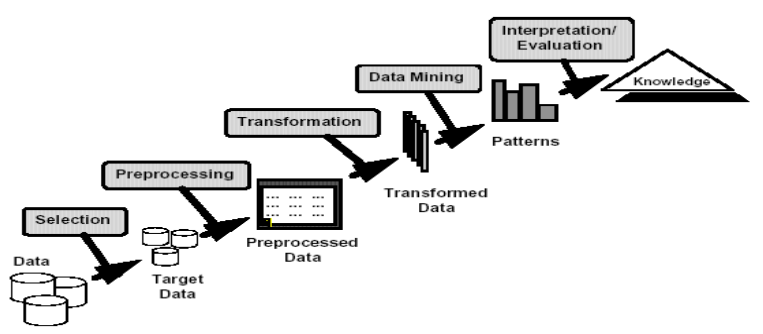

Gambar 1. Tahapan Data Mining

1. Tahap Pembersihan Data / Selection Yaitu dimana dilakukan proses pemilihan data yang akan digali (field yang dibutuhkan dalam proses data mining).

2. Tahap Preprocessing / Data Warehouse

Mengeliminasi data yang tidak konsisten. Contohnya menghapus data yang kosong.

3. Tahap Transformasi / Task-relevant Data

Proses pengubahan data menjadi bentuk lain, seperti jenis kelamin yang diganti menjadi 1 dan 0.

4. Tahap Data Mining

Data yang telah diolah diawal siap untuk digali, sehingga dapat menghasilkan informasi yang baru.

5. Tahap Evalusi

Setelah didapatkan hasil dari penambangan dan penggalian data maka hasil dari pengolahan data tersebut harus dievaluasi.[4]

\subsection{Penelitian Terkait}

Dalam seri penambangan data berkala, masalah mendasar adalah bagaimana menyajikan seri data berkala. Salah satu pendekatan yang umum adalah mengubah deret berkala menjadi domain lain sehingga dimensi yang dikurangi diikuti oleh 
mekanisme indeks, penelitian deret waktu tidak optimal karena masih terbatas pada data tambang belum mampu mewakili deret waktu [5], mampu menemukan pola dalam data deret waktu[6], pola perlu dikembangkan untuk mengubah pola menjadi aturan. Aturan dapat ditemukan dari data deret waktu, tetapi masih dibatasi oleh overfitting. Selanjutnya, ukuran kesamaan dalam seri periodik atau sub sekuens dan proses segmentasi adalah dua tugas utama untuk berbagai tugas yang tercakup dalam penambangan sekuensial periodik. Salah satu tugas penambangan ini adalah aturan penemuan. [7]meneliti mekanisme menemukan aturan untuk seri periodik. Namun algoritma mereka hanya dievaluasi untuk kecepatan proses dan kemudian hanya pada data acak. Tidak diperlihatkan apakah algoritma ini menemukan aturan secara umum dalam seri periodik. [8] menggunakan representasi linear bagian demi bagian untuk mendukung aturan penemuan dalam seri periodik. Algoritma mereka diuji pada data keuangan, dengan prediksi yang tepat 68\%. Metode yang paling banyak digunakan untuk penemuan aturan dalam literatur adalah dari [9]Mereka mengukur data dengan mengelompokkan K-means dari semua pelatihan dataset dan memasukkan data simbolik ke dalam algoritma asosiasi klasik dari penemuan aturan, kualitas aturan yang diinduksi dari data deret waktu dipengaruhi oleh parameter jumlah dan kluster. Keberhasilan suatu aturan diukur dengan menggunakan skor yang disebut ukuran-J. Tetapi pada telah ditunjukkan bahwa langkah kuantifikasi yang meliputi pengelompokan semua sub sekuens tidak akan dapat menghasilkan pusat kelompok. Masalah utama yang perlu ditangani dalam penambangan data berkala adalah jika hanya dengan visualisasi seri berkala yang dapat mencakup lebih dari ribuan pengamatan akan sangat sulit [10]. Bekerja dengan data mentah sangat tinggi akan sangat mahal dalam hal proses dan biaya penyimpanan. Oleh karena itu, kita memerlukan representasi atau abstraksi data tingkat tinggi. Penemuan aturan adalah salah satu cara melawan representasi. Sulit menyajikan data deret waktu dalam multi dimensi untuk ditambang

\subsection{Clustering}

Menurut [11], Clustering juga disebut sebagai segmentation. Metode ini digunakan untuk mengidentifikasi kelompok alami dari sebuah kasus yang di dasarkan pada sebuah kelompok atribut, mengelompokkan data yang memiliki kemiripan atribut. Selain itu cluster analysis merupakan pekerjaan mengelompokan data (objek) yang didasarkan hanya pada informasi yang ditemukan dalam data yang menggambarkan objek tersebut dan hubungan diantaranya. Tujuannya adalah agar objek - objek yang bergabung dalam sebuah kelompok merupakan objek - objek yang mirip (berhubungan) satu sama lain dan berbeda (tidak berhubungan) dengan objek dalam kelompok yang lain. Algoritma K-Means merupakan algoritma non hirarki yang berasal dari metode data clustering, Menurut [11]mengatakan bahwa metode K-Means ini mempartisi data kedalam kelompok sehingga data berkarakteristik sama dimasukan kedalam sat kelompok yang sama dan data yang berkarakteristik berbeda dikelompokkan kedalam kelompok yang lain. Adapun tujuan dari pengelompokan data ini adalah untuk meminimalkan fungsi objektif yang diset dalam proses pengelompokan, yang pada umumnya berusaha meminimalkan variasi didalam suatu kelompok dan memaksimalkan variasi antar kelompok. 
Dalam hierarchical clustering kita hitung jarak masing-masing obyek dengan setiap obyek yang lain. Selanjutnya kita temukan pasangan obyek yang jaraknya terdekat sehingga tiap obyek akan berpasangan dengan satu obyek atau dengan kelompok lain yang paling dekat jaraknya. Gambar 2 adalah flowchart yang menjelaskan urutan pengerjaan penelitian dengan menggunakan metode hierarchical clustering dan Kmeans.

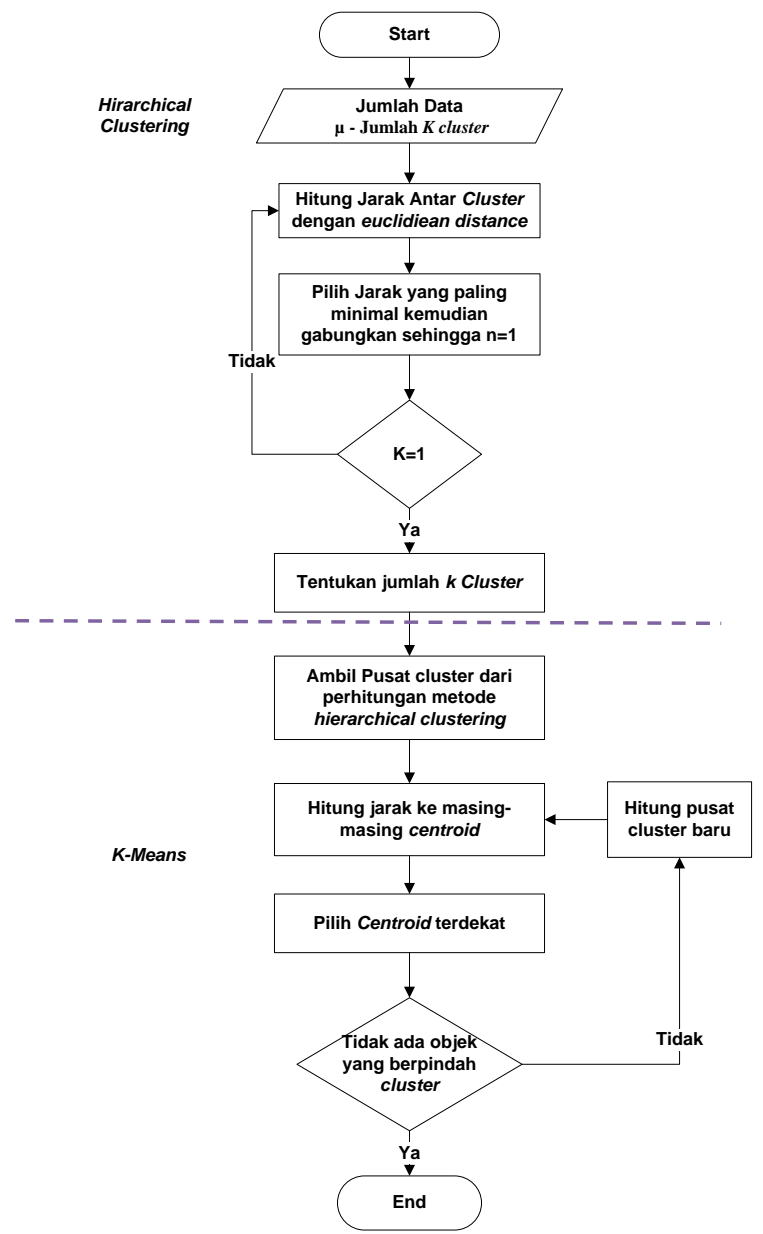

Gambar 2. Algoritma Hierarchical clustering dan K-means

Pengelompokan data dengan metode K-Means ini secara umum dilakukan dengan cara sebagai berikut:

1. Tentukan jumlah kelompok,

2. Alokasikan data kedalam kelompok secara acak,

3. Hitung pusat kelompok (sentroid/rata- rata) dari data yang ada di masing masing kelompok

4. Alokasikan masing - masing data ke centroid/rata-rata terdekat,

5. Kembali kelangkah 3, masih ada data yang berpindah kelompok, atau apabila ada perubahan nilai sentroid diatas nilai ambang yang ditentukan, atau apabila perubahan niai pada fungsi objektif yang digunakan masih diatas nilai ambang yang ditentukan.

Beberapa alternatif penerapan $K$-Means dengan beberapa pengembangan teori-teori penghitungan terkait telah diusulkan. Hal ini termasuk pemilihan: 
1. Distance space untuk menghitung jarak di antara suatu data dan centroid

Beberapa distance space telah diimplementasikan dalam menghitung jarak (distance) antara data dan centroid untuk prinsip dasar rumus dalam perhitungan istances dan Similarity Coeficients untuk beberapa pasang dari item Ecluidean Distance:

$$
\begin{aligned}
& d(x, y)=\sqrt{\left(x_{1}-y_{1}\right)^{2}+\left(x_{2}-y_{2}\right)^{2}+\ldots+\left(x_{p}-y_{p}\right)^{2}} \\
& \text { Atau } \\
& d(x, y)=\left[\sum_{i=1}^{p}\left|x_{i}-y_{i}\right|^{2}\right]^{1 / 2}
\end{aligned}
$$

Sedangkan untuk L2 (Euclidean) distance space, jarak antara dua titik dihitung menggunakan rumus sebagai berikut:

$$
D_{L 2}\left(x_{2}, x_{1}\right)=|| x_{2}, x_{1}||=\sqrt{\sum_{j=1}^{p}\left(x_{2 j}-x_{1 j}\right)^{2}}
$$

(3)

2. Metode pengalokasian data kembali ke dalam setiap cluster

Secara mendasar, ada dua cara pengalokasian data kembali ke dalam masingmasing cluster pada saat proses iterasi clustering. Kedua cara tersebut adalah pengalokasian dengan cara tegas (hard), dimana data item secara tegas dinyatakan sebagai anggota cluster yang satu dan tidak menjadi anggota cluster lainnya, dan dengan cara fuzzy, dimana masing-masing data item diberikan nilai kemungkinan untuk bisa bergabung ke setiap cluster yang ada

3. Objective function yang digunakan.

Objective function yang digunakan khususnya untuk Hard K-Means dan Fuzzy KMeans ditentukan berdasarkan pada pendekatan yang digunakan. Untuk metode Hard K-Means, objective function yang digunakan adalah sebagai berikut:

$$
J(U, V))=\sum_{k=1}^{N} \sum_{i=1}^{c} a_{i k} D\left(x_{k}, v_{i}\right)^{2}
$$

\section{METODE PENELITIAN}

Untuk menghasilkan hasil cluster dengan tingkat similarity terbaik secara umum tahapan dan kerangka kerja penelitian yang digunakan adalah dengan mengembangkan kerangka penelitian yang telah dikembangkan oleh [12], secara umum memiliki 4 tahapan yakni proses transforasi data menjadi grafik time series 2 dimensi, melakukan pembagian grafik menjadi beberapa siliding window, pengelompokan data grafik, membuat pengetahuan dalam bentuk rule dari hasil analisa cluster grafik, yang ditampilkan pada diagram blok berikut ini 


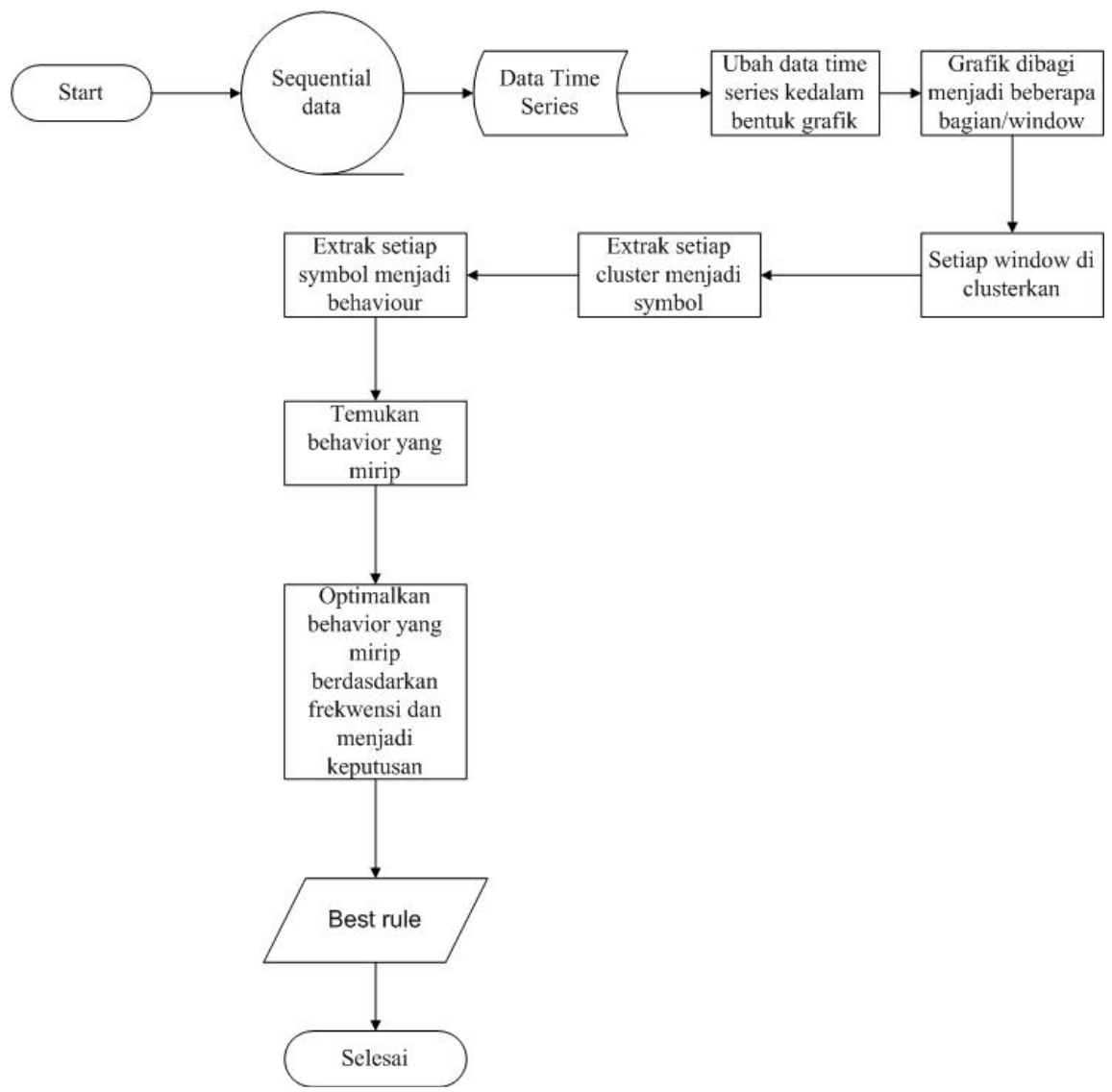

Gambar 3. Kerangka Kerja Penelitian

\section{HASIL DAN PEMBAHASAN}

Proses optimasi yang digunakan dalam menghasilkan cluster time series data mining adalah analisa pengelompokan cluster pada sliding window time series. Data yang digunakan adalah time series temperatur suhu rata-rata. Dengan menggunakan model hasil yang telah ditemukan, berikut ditampilkan pembahasan sebagai berikut

Tabel 1. Data Time Series Temperatur

\begin{tabular}{|l|l|l|l|l|l|l|l|}
\hline Tahun & Suhu $\left({ }^{\circ} \mathbf{C}\right)$ & Tahun & Suhu $\left({ }^{\mathbf{C}} \mathbf{C}\right)$ & Tahun & Suhu $\left({ }^{\mathbf{0}} \mathbf{C}\right)$ & Tahun & Suhu $\left({ }^{\mathbf{C}} \mathbf{C}\right)$ \\
\hline 1782 & 15,58 & 1885 & 14,57 & 1833 & 14,68 & 1936 & 14,8 \\
\hline 1783 & 15,96 & 1886 & 15,06 & 1834 & 17,41 & 1937 & 15,84 \\
\hline 1784 & 16,18 & 1887 & 14,72 & 1835 & 15,29 & 1938 & 14,93 \\
\hline 1785 & 14,43 & 1888 & 14,5 & 1836 & 14,66 & 1939 & 14,54 \\
\hline 1786 & 13,78 & 1889 & 15,13 & 1837 & 14,59 & 1940 & 14,51 \\
\hline 1787 & 14,66 & 1890 & 14,3 & 1838 & 14,32 & 1941 & 14,1 \\
\hline 1788 & 16,53 & 1891 & 14,72 & 1839 & 14,82 & 1942 & 15,68 \\
\hline 1789 & 15,25 & 1892 & 15,37 & 1840 & 14,68 & 1943 & 15,72 \\
\hline 1790 & 15,35 & 1893 & 15,13 & 1841 & 15,41 & 1944 & 15,18 \\
\hline 1791 & 15,75 & 1894 & 14,23 & 1842 & 15,56 & 1945 & 15,45 \\
\hline 1792 & 14,96 & 1895 & 15,46 & 1843 & 13,58 & 1946 & 15,76 \\
\hline 1793 & 15,72 & 1896 & 13,89 & 1844 & 14,07 & 1947 & 17,49 \\
\hline 1794 & 16,27 & 1897 & 14,52 & 1845 & 14,21 & 1948 & 14,94 \\
\hline 1795 & 15,56 & 1898 & 14,83 & 1846 & 17,23 & 1949 & 15,54 \\
\hline 1796 & 15,9 & 1899 & 15,01 & 1847 & 16,44 & 1950 & 16,9 \\
\hline 1797 & 16,58 & 1900 & 15,47 & 1848 & 15,55 & 1951 & 15,44 \\
\hline
\end{tabular}




\begin{tabular}{|c|c|c|c|c|c|c|c|}
\hline Tahun & Suhu $\left({ }^{\circ} \mathrm{C}\right)$ & Tahun & Suhu $\left({ }^{\circ} \mathrm{C}\right)$ & Tahun & Suhu $\left({ }^{\circ} \mathrm{C}\right)$ & Tahun & Suhu $\left({ }^{\circ} \mathrm{C}\right)$ \\
\hline 1798 & 16,09 & 1901 & 15,52 & 1849 & 15,12 & 1952 & 15,79 \\
\hline 1799 & 14,88 & 1902 & 13,93 & 1850 & 14,37 & 1953 & 15,38 \\
\hline 1800 & 15,97 & 1903 & 14,91 & 1851 & 13,44 & 1954 & 14,36 \\
\hline 1801 & 16,02 & 1904 & 15,76 & 1852 & 15,42 & 1955 & 14,46 \\
\hline 1802 & 15,55 & 1905 & 15,52 & 1853 & 15,16 & 1956 & 14,43 \\
\hline 1803 & 14,84 & 1906 & 14,36 & 1854 & 14,81 & 1957 & 14,18 \\
\hline 1804 & 15,99 & 1907 & 14,8 & 1855 & 14,88 & 1958 & 16,01 \\
\hline 1805 & 14,29 & 1908 & 14,74 & 1856 & 14,93 & 1959 & 15,58 \\
\hline 1806 & 15,72 & 1909 & 13,54 & 1857 & 15,74 & 1960 & 14,77 \\
\hline 1807 & 17,43 & 1910 & 13,76 & 1858 & 15,14 & 1961 & 15,36 \\
\hline 1808 & 16,94 & 1911 & 16,27 & 1859 & 16,39 & 1962 & 14,73 \\
\hline 1809 & 15,73 & 1912 & 13,3 & 1860 & 14,46 & 1963 & 15,47 \\
\hline 1810 & 15,87 & 1913 & 13,4 & 1861 & 15,4 & 1964 & 16,24 \\
\hline 1811 & 17,21 & 1914 & 14,08 & 1862 & 15,5 & 1965 & 14,13 \\
\hline 1812 & 15,43 & 1915 & 15,06 & 1863 & 15,45 & 1966 & 14,84 \\
\hline 1813 & 14,1 & 1916 & 13,93 & 1864 & 14,1 & 1967 & 15,58 \\
\hline 1814 & 13,72 & 1917 & 16,78 & 1865 & 16,3 & 1968 & 14,63 \\
\hline 1815 & 14,65 & 1918 & 14,56 & 1866 & 15,09 & 1969 & 15,1 \\
\hline 1816 & 13,34 & 1919 & 14,65 & 1867 & 14,72 & 1970 & 15,02 \\
\hline 1817 & 15,04 & 1920 & 15 & 1868 & 16,62 & 1971 & 15,16 \\
\hline 1818 & 14,93 & 1921 & 16,16 & 1869 & 14,87 & 1972 & 14 \\
\hline 1819 & 15,68 & 1922 & 14,62 & 1870 & 14,72 & 1973 & 15,68 \\
\hline 1820 & 14,5 & 1923 & 14,99 & 1871 & 14,44 & 1974 & 14,5 \\
\hline 1821 & 14,13 & 1924 & 14,62 & 1872 & 15,22 & 1975 & 15,4 \\
\hline 1822 & 16,17 & 1925 & 14,59 & 1873 & 15,14 & 1976 & 15,12 \\
\hline 1823 & 15,22 & 1926 & 14,3 & 1874 & 15,14 & 1977 & 14,54 \\
\hline 1824 & 14,71 & 1927 & 15,15 & 1875 & 15,91 & 1978 & 13,94 \\
\hline 1825 & 15,16 & 1928 & 15,13 & 1876 & 14,71 & 1979 & 14,78 \\
\hline 1826 & 15,65 & 1929 & 15,87 & 1877 & 14,46 & 1980 & 14,28 \\
\hline 1827 & 15,71 & 1930 & 15,31 & 1878 & 14,71 & 1981 & 15,04 \\
\hline 1828 & 14,98 & 1931 & 14,78 & 1879 & 14,13 & 1982 & 16,06 \\
\hline 1829 & 14,15 & 1932 & 15,94 & 1880 & 14,24 & 1983 & 15,94 \\
\hline 1830 & 15,12 & 1933 & 14,42 & 1881 & 14,78 & 1984 & 13,91 \\
\hline 1831 & 14,64 & 1934 & 15,83 & 1882 & 13,53 & 1985 & 15,36 \\
\hline 1832 & 14,51 & 1935 & 15,55 & 1883 & 14,53 & 1986 & 15,34 \\
\hline 1884 & 14,48 & 1987 & 14,67 & 1988 & 15,88 & & \\
\hline
\end{tabular}

Data pada tabel 1 diproses dengan melakukan plot data menjadi grafik time series

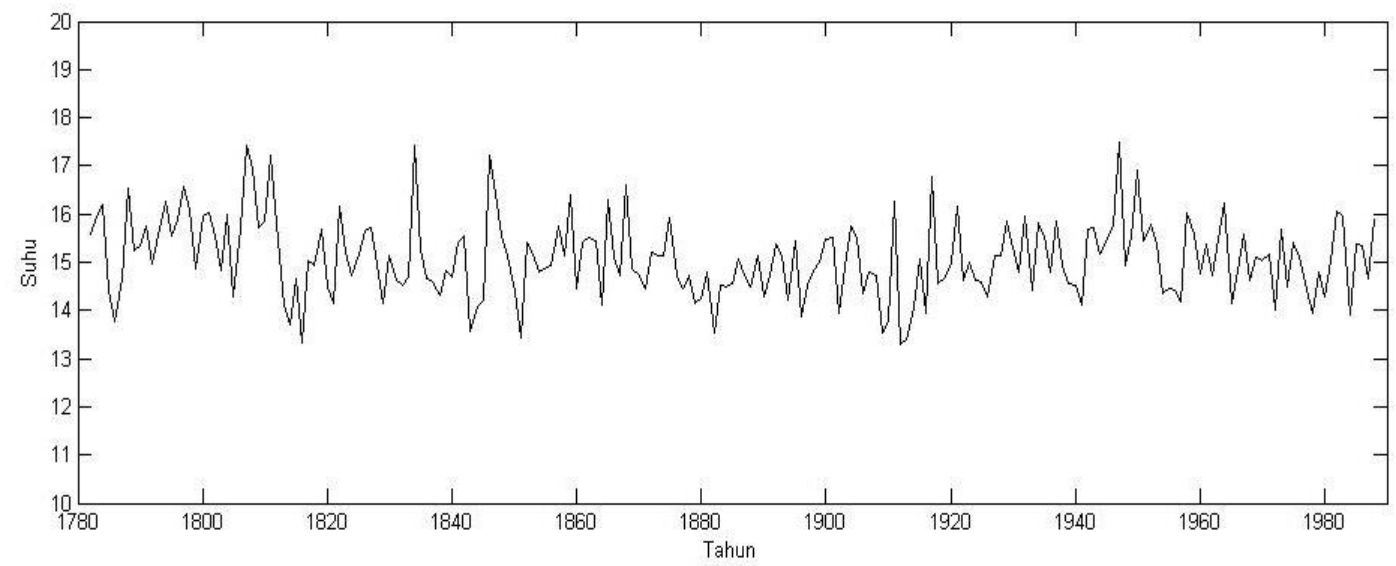

Gambar 4. Grafik Time Series Temperatur 
Gambar 4. menunjukkan hasil plot data time series temperatur terhadap waktu(tahun), terlihat jelas bahwa grafiknya tidak linear terjadi perubahan bentuk seiring berjalannya waktu setiap tahun. Secara visual sangat sulit dianalisis jika menggunakan analisis pola, sulit mengidentifikasi aturan yang terkandung didalamnya dan potensial menarik. Langkah berikutnya membagi grafik menjadi beberapa window yang disebut dengan sub sequence time series, dalam kasus ini dibagi dalam 10 window dan selanjutnya window tersebut akan menjadi pusat analisis

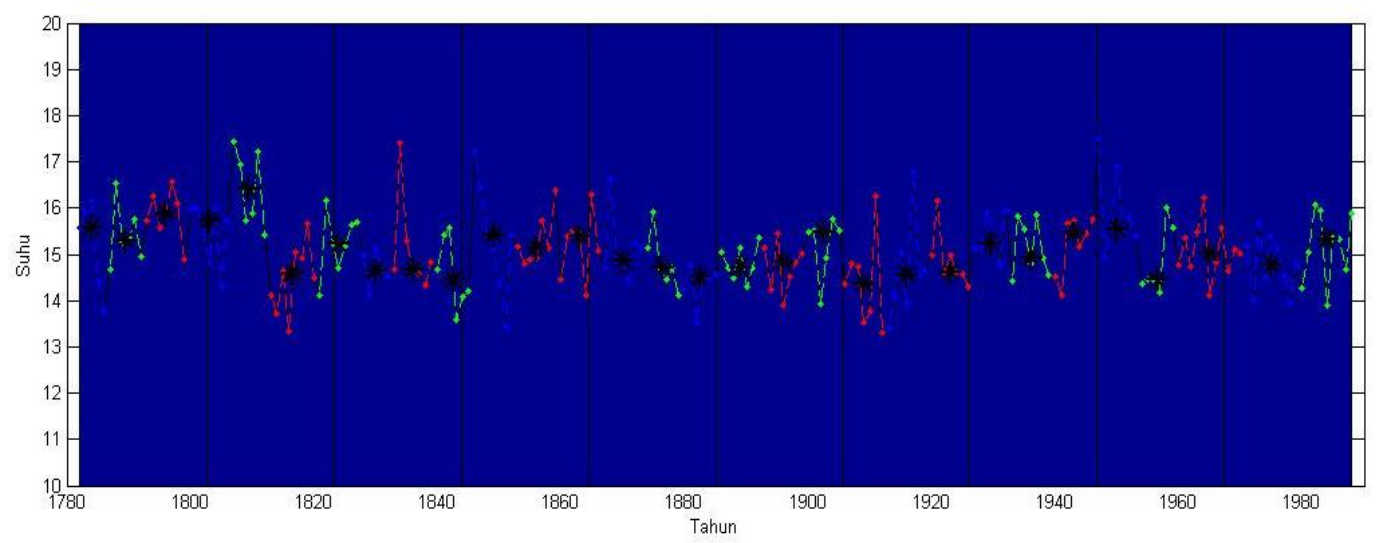

Gambar 5. Hasil Analisis Window

Gambar 5 menunjukkan hasil analisis untuk setiap window, setiap window menghasilkan titik titik yang diperoleh melalui perhitungan jarak similarity, titik tersebut merupakan hasil trend untuk window seiring dengan terjadinya perubahan waktu, data setiap analisis window disajikan pada tabel 2

Tabel 2. Data Analisis Window

\begin{tabular}{|c|c|c|c|}
\hline Window & Tahun & $\begin{array}{l}\text { Pusat } \\
\text { Cluster }\end{array}$ & Pengetahuan Baru \\
\hline \multirow[t]{3}{*}{ I } & \multirow[t]{3}{*}{$\begin{array}{l}1780- \\
1800\end{array}$} & $\begin{array}{l}1784-15,6 \\
{ }^{\circ} \mathrm{C}\end{array}$ & \multirow[t]{3}{*}{ Suhu cenderung $15,3^{\circ} \mathrm{C}$ sampai dengan $15,9^{\circ} \mathrm{C}$} \\
\hline & & $\begin{array}{l}1796-15,9 \\
{ }^{\circ} \mathrm{C}\end{array}$ & \\
\hline & & $\begin{array}{l}1789-15,3 \\
{ }^{0} \mathrm{C}\end{array}$ & \\
\hline \multirow[t]{3}{*}{ II } & \multirow[t]{3}{*}{$\begin{array}{l}1801- \\
1820\end{array}$} & $\begin{array}{l}1816-14,6 \\
{ }^{0} \mathrm{C}\end{array}$ & \multirow[t]{3}{*}{$\begin{array}{l}\text { Suhu cenderung } 14,6{ }^{\circ} \mathrm{C} \text { sampai dengan } 16,4{ }^{\circ} \mathrm{C} \text {, terjadi } \\
\text { peningkatan suhu signifikan pada tahun } 1801 \text { yakni } 16,4{ }^{\circ} \mathrm{C}\end{array}$} \\
\hline & & $\begin{array}{l}1809-16,4 \\
{ }^{0} \mathrm{C}\end{array}$ & \\
\hline & & $\begin{array}{l}1803-15,7 \\
{ }^{\circ} \mathrm{C}\end{array}$ & \\
\hline \multirow[t]{3}{*}{ III } & \multirow[t]{3}{*}{$\begin{array}{l}1821- \\
1840\end{array}$} & $\begin{array}{l}1836-14,7 \\
{ }^{0} \mathrm{C}\end{array}$ & \multirow[t]{3}{*}{ Suhu cenderung $14,6^{\circ} \mathrm{C}$ sampai dengan $15,42^{\circ} \mathrm{C}$} \\
\hline & & $\begin{array}{l}1824-15,2 \\
{ }^{0} \mathrm{C}\end{array}$ & \\
\hline & & $\begin{array}{l}1830-14,6 \\
{ }^{0} \mathrm{C}\end{array}$ & \\
\hline \multirow[t]{2}{*}{ IV } & \multirow[t]{2}{*}{$\begin{array}{l}1841- \\
1860\end{array}$} & $\begin{array}{l}1856-15,1 \\
{ }^{0} \mathrm{C}\end{array}$ & \multirow[t]{2}{*}{ Suhu cenderung $14,4{ }^{\circ} \mathrm{C}$ sampai dengan $15,4{ }^{\circ} \mathrm{C}$} \\
\hline & & $\begin{array}{l}1842-14,4 \\
{ }^{\circ} \mathrm{C}\end{array}$ & \\
\hline
\end{tabular}




\begin{tabular}{|c|c|c|c|}
\hline & & $\begin{array}{l}1849-15,4 \\
{ }^{0} \mathrm{C}\end{array}$ & \\
\hline \multirow[t]{3}{*}{ V } & \multirow[t]{3}{*}{$\begin{array}{l}1861- \\
1880\end{array}$} & $\begin{array}{l}1863-15,1 \\
{ }^{\circ} \mathrm{C}\end{array}$ & \multirow[t]{3}{*}{ Suhu cenderung $14,7^{\circ} \mathrm{C}$ sampai dengan $15,4^{\circ} \mathrm{C}$} \\
\hline & & $\begin{array}{l}1876-14,4 \\
{ }^{0} \mathrm{C}\end{array}$ & \\
\hline & & $\begin{array}{l}1870-15,4 \\
{ }^{0} \mathrm{C}\end{array}$ & \\
\hline \multirow[t]{3}{*}{ VI } & \multirow[t]{3}{*}{$\begin{array}{l}1881- \\
1900\end{array}$} & $\begin{array}{l}1896-14,8 \\
{ }^{0} \mathrm{C}\end{array}$ & \multirow[t]{3}{*}{ Suhu cenderung $14,5^{\circ} \mathrm{C}$ sampai dengan $14,8^{\circ} \mathrm{C}$} \\
\hline & & $\begin{array}{l}1889-14,7 \\
{ }^{0} \mathrm{C}\end{array}$ & \\
\hline & & $\begin{array}{l}1882-14,5 \\
{ }^{\circ} \mathrm{C}\end{array}$ & \\
\hline \multirow[t]{3}{*}{ VII } & \multirow[t]{3}{*}{$\begin{array}{l}1901- \\
1920\end{array}$} & $\begin{array}{l}1990-14,4 \\
{ }^{0} \mathrm{C}\end{array}$ & \multirow[t]{3}{*}{ Suhu cenderung $14,4^{\circ} \mathrm{C}$ sampai dengan $15,5^{\circ} \mathrm{C}$} \\
\hline & & $\begin{array}{l}1902-15,5 \\
{ }^{0} \mathrm{C}\end{array}$ & \\
\hline & & $\begin{array}{l}1916-14,6 \\
{ }^{0} \mathrm{C}\end{array}$ & \\
\hline \multirow[t]{3}{*}{ VIII } & \multirow[t]{3}{*}{$\begin{array}{l}1921- \\
1940\end{array}$} & $\begin{array}{l}1923-14,6 \\
{ }^{\circ} \mathrm{C}\end{array}$ & \multirow[t]{3}{*}{ Suhu cenderung $14,6^{\circ} \mathrm{C}$ sampai dengan $15,2^{\circ} \mathrm{C}$} \\
\hline & & $\begin{array}{l}1936-14,9 \\
{ }^{0} \mathrm{C}\end{array}$ & \\
\hline & & $\begin{array}{l}1929-15,2 \\
{ }^{0} \mathrm{C}\end{array}$ & \\
\hline \multirow[t]{3}{*}{ IX } & \multirow[t]{3}{*}{$\begin{array}{l}1941- \\
1960\end{array}$} & $\begin{array}{l}1943-15,4 \\
{ }^{\circ} \mathrm{C}\end{array}$ & \multirow[t]{3}{*}{ Suhu cenderung $14,4^{\circ} \mathrm{C}$ sampai dengan $15,5^{\circ} \mathrm{C}$} \\
\hline & & $\begin{array}{l}1956-14,4 \\
{ }^{0} \mathrm{C}\end{array}$ & \\
\hline & & $\begin{array}{l}1950-15,5 \\
{ }^{0} \mathrm{C}\end{array}$ & \\
\hline \multirow[t]{3}{*}{$\mathrm{X}$} & \multirow[t]{3}{*}{$\begin{array}{l}1961- \\
1980\end{array}$} & $\begin{array}{l}1965-15,0 \\
{ }^{0} \mathrm{C}\end{array}$ & \multirow[t]{3}{*}{ Suhu cenderung $14,8^{\circ} \mathrm{C}$ sampai dengan $15,3^{\circ} \mathrm{C}$} \\
\hline & & $\begin{array}{l}1984-15,3 \\
{ }^{0} \mathrm{C}\end{array}$ & \\
\hline & & $\begin{array}{l}1975-14,8 \\
{ }^{0} \mathrm{C}\end{array}$ & \\
\hline
\end{tabular}

\section{KESIMPULAN}

Berdasarkan analisa pengetahuan dari setiap window maka dapat ditentukan rule yang berpotensial menarik serta memangkas rule yang tidak menarik, rule yang cenderung memiliki redundansi, rule yang tidak memiliki redundansi, maka best rulenya adalah suhu cenderung pada angka $14{ }^{\circ} \mathrm{C}$ sampai dengan $15{ }^{\circ} \mathrm{C}$ setiap tahun, dan terjadi peningkatan suhu yang significan pada tahun 1809. Jarak kedekatan dengan menggunakan manhattan City mampu menemukan pengetahuan dengan analisis cluster.

\section{DAFTAR PUSTAKA}

[1] U. Fayyad, G. Piatetsky-Shapiro, and P. Smyth, "From Data Mining to Knowledge Discovery in Databases," AI Mag., vol. 17, no. 3, p. 37, 1996.

[2] R. Agrawal, C. Faloutsos, and A. Swami, "Efficient Similarity Search In Sequence Databases," Springer, 1993. 
[3] K. Luthfi emha taufiq, Algoritma Data Mining. Yogyakarta: ANDI, 2009.

[4] R. Buaton, Y. Sundari, and Y. Maulita, "Clustering Tindak Kekerasan Keker Pada Anak Menggunakan Algoritm oritma K-Means Dengan Perbandingan ingan Jarak Kedekatan Manhattan City Dan an Eu Euclidean," vol. 1, no. 2, 2016.

[5] T. Fu, "Engineering Applications of Artificial Intelligence A review on time series data mining," Eng. Appl. Artif. Intell., vol. 24, no. 1, pp. 164-181, 2011.

[6] E. Keogh, "Clustering of Time Series Subsequences is Meaningless : Implications for Previous and Future Research," 2005.

[7] S. Park and wesley Chu, "Discovery and matching elastic rules from sequence database," Fundam. Inform., 2001.

[8] H. Wu, B. Salzberg, and D. Zhang, "Online Event-driven Subsequence Matching over Financial Data Streams," Sigmod Conf., 2004.

[9] G. Das, K. Lin, and H. Mannila, "Rule discovery from time series," Am. Assoc. Artif. Intell., 1998.

[10] J. Lin, S. Lonardi, J. Lin, and S. Lonardi, “Visualizing and Discovering Non-Trivial Patterns In Large Time Series Databases Short running title : Time Series Visualization Visualizing and Discovering Non-Trivial Patterns In Large Time Series Databases," 2005.

[11] E. Prasetyo, Data Mining : Konsep Dan Aplikasi Menggunakan Matlab. Yogyakarta: ANDI, 2012.

[12] K. U. Yoshiki Tanaka, Kazuhisa Iwamoto, "Discovery of Time-Series Motif from MultiDimensional Data Based on MDL Principle," Springer Sci. + Bus. Media, Inc. Manuf. Netherlands, no. 2000, pp. 269-300, 2005. 